\title{
Dimensions of Entrepreneurial Orientation and SME Performance: Moderating Effect of Absorptive Capacity of the Firm
}

\author{
H. M. A. Herath \\ Department of Business Management, Wayamba University of Sri Lanka \\ herathhma@wyb.ac.lk
}

\begin{abstract}
This paper investigates a model of SME performance based on the dimensions of entrepreneurial orientation and absorptive capacity of the firm. The model tested the direct effects of innovativeness, risk-taking and proactiveness on firm performance and the moderating role of absorptive capacity on the relationship between the dimensions of entrepreneurial orientation and firm performance. Structural equation modelling with multi group analysis was used to test the model in the context of small and medium scale hotel and restaurant industry in Sri Lanka. Results indicate that highly entrepreneurial-oriented SMEs with high level of absorptive capacity achieve higher level of performance.
\end{abstract}

Keywords: SME performance, Entrepreneurial orientation, Absorptive capacity

\section{Introduction}

Highly and constantly performing Small and Medium scale Enterprises (SME) sector is one of the most significant features of the countries that had achieved high level of development. Therefore, it is considered as the "backbone" of any economy (Wymenga, Spanikowa, Baker, Konings, \& Canton, 2012). In many of the developing countries, more than 75 percent of total business entities are SMEs and they contribute to the major portion of gross domestic product making it is the engine behind economic expansion. An impressive empirical support has been received for their importance to those countries that are in a continuous struggle to achieve their socio-economic developmental targets (Subhan, Mehmood, \& Sattar, 2013; Asian Productivity organization, 2011).
Due to their utmost importance, performance of SME has been the focus of many prior researchers making it one of the most widely used construct as a dependent variable (Rogers \& Wright, 1998; March \& Sutton, 1997; Carton \& Hofer, 2010). Many of the previous SME performance models have incorporated both internal and external variables to explain the complex relationships with performance (eg. Islam, Khan, \& Obaidullah, 2011; Beneki \& Papastathopoulos, 2011; Enriquez, Adame, \& Camacho, 2011; Leitner \& Idenberg, 2010; Inmyxai \& Takahashi, 2009; Mancinelli \& Mazzanti, 2009). But findings are inconsistent and any of the combination of variables has not explained the phenomenon to a satisfactory extent. According to Agrawal (2007), this inconsistency may be because of not investigating complex models with appropriate mediating and moderating paths 
between predictors and criterion. He further argued that research models using mediating and moderating paths are more successful than the models testing only direct effects. Accordingly, it is obvious that complex models of firm performance are yet to be investigated for further clarification of the phenomenon.

Generally, it is believed that being entrepreneurial-oriented is critical for the long-term survival and higher level of performance of the firm. Many researchers argue that entrepreneurialoriented firms are capable of easily adjusting to the dynamic environmental conditions (Lumpking \& Dess, 1996; Covin \& selvin, 1991). Entrepreneurial Orientation (EO) has been researched as one of the pivotal construct within the strategic management and entrepreneurship. The performance models in which the EO-performance relationship has been investigated includes not only bivariate relationships but also multivariate relationships with mediating and moderating variables (Covin \& Selvin, 1989). In the entrepreneurial literature in last two decades, the relationship between EO and firm performance has received considerable attention. However, the magnitude of the relationship seems vary across different studies and contexts. Some studies found that firms that adopt EO perform well than others (Kreiser \& Davis, 2010) while some studies found weak relationship between two constructs (Baker \& Sinkula, 2009). Some other studies have not fond a significant relationship (Tang \& Koveos, 2004). Others reported that the relationship represents inverted $U$ shape rather than straightforward
(Bhuian, Menguc \& Bell, 2005). Thus, a considerable variation exists in the relationship between the two constructs. The reasons for the variations are attributed to the influence of organizational and environmental variables to the relationship. Consequently, mediating and moderating effects may make the relationship more strong and directional.

Firm performance is also influenced by the way of absorbing and accumulating knowledge. Absorptive capacity (ACAP) of the firm is now considered as critical not only for the success of larger firms but also SMEs (Zonooz, Farzam, Satarifar, \& Bakhdhi, 2011; Klette \& Johensen, 1998). Due to the importance of the construct, many scholars have suggested further investigation to clarify its role (Sun \& Anderson, 2010; Zhou \& Li, 2010). Some others have emphasized the need of clarifying its role in different contexts such as developing countries (Astrid, Cristina, \& Ruzana, 2008), service industry (Harvey, Skelcher, Jas, \& Walshe, 2010).

Existing literature reveals that many of the previous performance models have used the construct as a predictor variable (Yeoh, 2009; Zahara \& George, 2002; Lane, Salk, \& Lyles, 2001). Only four studies have investigated the moderating role of the construct. Moderating role in the relationship between knowledge acquisition and performance is the focus of two studies (Lin-Van, De-Van, \& Yun- Horng, 2010; Wang, \& Han, 2011). Another single study considered the moderating role of ACAP in the relationship between innovative 
performance and market orientation (Yang-Chao, Shun-Lin, Lin-Cheng, \& Chia-Liao, 2011) while another study considered the relationship between organizational resources and performance (Kim, Zhan, \& Erramilli, 2011). Also only two studies have investigated the mediating role of the construct (Zhang, 2009; Hou, 2008). Accordingly, the role of ACAP in SME performance models is yet to be clarified.

\section{Problem of the Study}

The SME sector of many of developing nations faces many constraints such as technological backwardness, low level of human resource skills, weak management systems and entrepreneurial capabilities, unavailability of appropriate and timely information, insufficient use of information technology and poor product quality. Consequently, the economic contribution of SMEs in developing countries is currently far behind compared to developed countries (Altenburg \& Eckhardt, 2006; Emine, 2012; Panday, 2012; Asian Productivity Organization, 2011). Accordingly, low level of performance in SMEs sector is one of the key issues in most of the developing countries though they have been expected to play a critical role in their economies. The current globalized competitive rivalry has multiplied the importance of the issue. Especially the global competition emerging from widespread e- commerce activities has forced to revisit the issue in the context of developing countries.

\section{Literature Review Firm Performance}

Firm performance generally refers to the organizational success and success is considered as achieving organizational goals (Foley \& Green, 1989). According to Kaplan and Norton (1996), firm performance is a multidimensional concept and all aspects of performance are relevant to the success of the organization. Firm performance has been widely focused by many researchers mainly in two disciplines. It is at the heart of strategic management discipline (Venkatraman \& Ramanujam, 1986) and measure the construct mainly in financial aspects (Rogers \& Wright, 1998). In entrepreneurship, researchers have attempted to explain the variation of the firm performance (Carton \& Hofer, 2010; Murphy, Trailer, \& Hill, 1996; Brush \& Vanderwerf, 1992). Wide range of measures of firm performance such as profitability (eg. net profit, ROI) growth (eg. market share, turnover) and survival have been used by researchers making little consensus on the measurement (Carton \& Hofer, 2010; Brush \& VanderWerf, 1992).

\section{Entrepreneurial Orientation and its Dimensions}

EO is considered as a strategic element, which covers the entrepreneurial aspects of the firm (Wiklund \& Shepherd, 2005; Covin \& Selvin, 1991; Hult et al., 2004; Bhuian et al. 2005). The construct is viewed as a characteristic of organization which represents managemnets' entrepreneurial style (Miller, 1983). Covin and Selvin, (1989) argued that EO is the summation of the extent to 
which top managers are inclined to take risks, favour for innovation and the way of facing competition. Accordingly, the concept encompasses of three dimensions as proactiveness, innovativeness and risk taking (Miller, 1983; Covin \& Selvin, 1991). Lumpkin and Dess (1996) conceptualized the concept with five dimensions namely competitive aggressiveness, proactiveness, risk taking, innovativeness and autonomy. They further posited that these dimensions might vary independently depending on the organizational context.

\section{Entrepreneurial Orientation and Firm Performance}

Atuahene-Gima and Ko, (2001) investigated the effect of EO on small firms' product innovative performance and found that high EO positively affect performance. Baker and Sinkula, (2009) examined the direct effect EO on profitability in a sample of SMEs in USA and found that EO profitability through innovation success. Barrett, Balloun, and Weinstein, (2005) found that EO correlates with performance in non-for-profit organizations. Becherer and Maurer, (1997) investigated the effect of EO in entrepreneur-led US SMEs. Results indicated that EO correlates with performance. Wang, (2008) found positive effect of EO on performance. Frishammar and Horte, (2007) proved significant effect of EO on new product performance of medium scale manufacturing firms in Sweden. Results also proved innovation dimension of EO positively related with new product performance. $\mathrm{Li},(2005)$ found that EO have positive effects on managerial networking and in turn increase the performance in
Chinese foreign invested firms. Li, Liu and Zhao, (2006) in a study in Chinese firms indicated that EO has positive effects on new product performance. Li, Zhao, Tan, and Liu, (2008) in a study proved that innovativeness and proactiveness dimensions of EO strengthen the positive relationship between market orientation and performance. Liu, Luo, and Shi, (2003) found that higher level of EO, increase the competitive advantage of state owned Chinese companies. Hult, Hurley, and Knight, (2004) found, in large-scale industrial firms, positive relationship among EO innovation and performance. Kropp, Lindsay, and Shoham, (2008) indicated that EO lead to lower performance in the early stage of international business ventures. Roukonen and Saarenketo, (2009) in a case study analysis of small-scale Finnish software firms found that EO combined with strong learning orientation and market orientation has significant effect on internationalization. Luo, Sivakumar, and Liu, (2005) found that EO affect organizational performance. Schindehutte, Morris, and Kocak, (2008) in a conceptual study emphasized that EO, would influence how firms perform. Tzokas, Carter, and Kyriazopoulos, (2001) found that EO improve the operational competencies of in small scale manufacturing firms in Greece. Tajeddini, (2010) investigated the effect of EO on the performance of hotel industry in Switzerland and found that EO has an effect on the business performance. Barrett, Balloun, and Weinstein, (2005a) claimed that the effect of EO on performance depends on the industry or market. Hoq, and Chauhan, (2011) conducted a study in SMEs in 
Bangladesh and found that EO positively related to firm performance in hostile business environment. Chandrakumara, De Zoysa, and Manawaduge, (2011) shown that EO produces more positive effect on the performance of small firms than medium scale firms do. Fauzul, Takenouchi, \& Yukiko, (2010) in a study in Sri Lankan SMEs, proved positive relationship between EO and firm performance.

\section{Absorptive Capacity and Firm Performance}

Cohen and Levinthal (1989, 1990) defined ACAP as "the ability of a firm to recognize new external information, assimilate it and apply it to commercial ends". Zahra and George (2002) reconceptualized the concept under two major areas; Potential ACAP and realized ACAP.

ACAP has been investigated by number of performance models in prior research. Among them many studies have proven positive relationship with firm performance (George, Zahra, Wheatley, \& Khan, 2001; Lane, Salk, \& Lyles, 2001; Yeoh, 2009; Lane, Koka, \& Pathak, 2006; Lichtenthaler, 2009; Bergh \& Lim, 2008; Sher \& Lin, 2006; Murray \& Peyrefitte, 2007; Flatten, Greve, \& Brettel, 2011; Ng, 2011; Parida, 2009; Zahra \& George, 2002). Cohen and Levinthal (1990) claimed that it creates firm's competitive advantage. Deeds (2001) found ACAP positively influencing new wealth creation. Huang and Rice (2009) and Jolly and Therin (2007) found that firms easily assimilate knowledge to develop innovations. Muscio (2007) proved that ACAP improves the collaboration with other organizations. Hayton and Zahra (2005) found that ACAP increases ability to acquire additional resources. Liao, Welsch, and Stoica (2003) found that knowledge acquisition positively related to organizational responsiveness of growth-oriented SMEs. Brettel, Greve, and Flatten (2011) suggested curvilinear relationship between ACAP and performance of the firm.

Some other studies have tested ACAP as a moderator in performance models and found significant effects. (LinVan, De-Van, \& Yun- Horng, 2010; Wang, \& Han, 2011; Yang-Chao, Shun-Lin, Lin-Cheng \& Chia-Liao, 2011; Kim, Zhan, \& Erramilli, 2011). Hou, (2008) and Zhang (2009) proved a significant mediating role of absorptive capacity in performance models.

\section{Research Model and Hypotheses}

EO comprise constellation of proactiveness, innovativeness, and risk-taking supposing that it is a combination of the value position of the firm in the markets, its resources, and behavioural patterns relating to how the organization transforms its resources into performance (Hakala, 2010). These resources and behaviours lead organizations to perform well by adjusting continuously to the dynamic environment, adapting new internal and external conditions, and responding customer needs and competitors' challenges (Sinkula, Baker, \& Noordewier, 1997; Lumpkin \& Dess, 1996; Covin \& Selvin, 1989). Based on this direct relationship between EO and firm performance 
following hypotheses can be formulated.

$\mathbf{H}_{1}$ : There is a positive relationship between proactiveness and firm performance.

$\mathbf{H}_{2}$ : There is a positive relationship between Innovativeness and firm performance.

H3: There a positive relationship between risk-taking and firm performance.

These hypotheses for the direct paths of the research model were underpinned by the theory of Entrepreneurial Orientation by Lumpkin \& Dess, 1996; Covin \& Selvin, 1989 and Covin and Lumpkin, (2011).

The resource based and knowledgebased views of the firm has stressed that resources alone cannot achieve the competitive advantage and the firm's with stronger dynamic capabilities are capable of exploiting available bulk of organizational resources (Grant, 1996; Newbert, Gopalakishnan, \& Kirchoff, 2008; Teece \& Pisano, 1994). Newbert et al. (2008) reported that the higher level of firm's internal capabilities of leveraging resources leads the firms to outperform their rivals with low level of such capacities.

Some scholars posited that ACAP plays a pivotal role among other dynamic capabilities in exploiting the prevailing bulk of organizational resources since knowledge acquisition and absorption are key features of exploiting opportunities (Frishammar \& Andersson, 2009; Hou, 2008; Sun \& Anderson, 2010). This theoretical premise provides a base for reasonable assumption that the existence of ACAP that can exploit organizational resources would make the relationship between EO and firm performance stronger and directional. Accordingly, this study formulated following three hypotheses.

H4: Relationship between proactiveness and firm performance is moderated by absorptive capacity of the firm.

H5: Relationship between Innovativeness and firm performance is moderated by absorptive capacity of the firm.

H6: Relationship between risk-taking and firm performance is moderated by absorptive capacity of the firm.

These three hypotheses based on the moderating paths of the research model were grounded on the theory of Dynamic Capabilities by (Teece \& Pisano, 1994)

The graphical representation of the research model is shown in the figure 01 in appendices.

\section{Method}

\section{Research Design and Sample}

A field survey was conducted in randomly selected sample of small and medium scale hotel and restaurants in Sri Lanka. A questionnaire was administered among 380 respondents who dispersed all over the island. The data collection process went through eight weeks of time period and 30 responses were eliminated after scrutinizing for incompleteness and 
treating univariate and multivariate outliers.

\section{Measures}

Entrepreneurial orientation which comprised with innovativeness, risk taking and proactiveness was measured by 12 item scale developed by Covin and Selvin (1989). Five-point Likert scale ranging from 1 (strongly disagree) to 5 (strongly agree) was used to measure responses to each item.

\section{Data Analysis}

Data analysis was done by structural equation modelling. Three direct structural paths were estimated testing the direct effect model and moderating effects were estimated with multi group analysis. First, the respondents on the moderating variable ACAP were divided into two groups. Respondents with mean for absorptive capacity greater than 3.5 were considered as high ACAP group while mean for ACAP less than 3.5 were considered as low ACAP group. This process created two groups with 155 respondents in high ACAP group and 195 for low ACAP group.

Second, the measurement invariance across two groups was evaluated by testing the measurement model as configural invariance model seperately in two groups. If the difference of overall model fit across two groups is not significant, the measurement invariance was established and groups are therefore suitable for comparison (Schoot, Lugtig, \& Hox, 2012).

Having assured the measurement invariance, the baseline model was estimated across low and high groups with all free path estimates. Then the constrained model with the paths from proactiveness, innovativeness and risktaking to performance constrained to equal values was assessed across two groups. Finaly, $\chi^{2}$ difference between baseline, non-constrained model and constrained model were conducted. If the $\chi^{2}$ difference is statistically significant, there exists a moderating effect.

$\chi^{2}$ difference idicates only the existance of a moderating effect. To determine direction and the magnitude of moderating effect, regression weights and squared multiple correlations were examined. If the regression weights of the moderating paths of higher ACAP group are higher than that of low ACAP group, higher level of moderating effect exists. Similarly higher squared multiple correlations for higher ACAP group denotes high level of moderating effects.

\section{Results}

The structural model with direct relationships proved overall model fit with $\chi^{2}=239.063$ and $d f=113$. All overall model fit indices recorded a good model fit $(\mathrm{CMIN} / \mathrm{df}=2.11$, $\mathrm{CFI}=.954, \quad$ and $\mathrm{RMSEA}=.047)$. Graphical output for the direct effects is shown in the figure 2. Standardised regression weights for direct paths in the table 1 show that all values are positive and significant at 001 level.

The baseline model for low and high ACAP groups given in the figure 3 and 4 well fit across both groups with $\chi^{2}=$ 406.755 and $d f=226$. All overall model fit indices recorded a good model fit $(\mathrm{CMIN} / \mathrm{df}=1.800, \mathrm{CFI}=.932$, and RMSEA=.048). 
The constrained models with structural parameters on proactiveness, innovativeness, risk-taking and performance constrained to fixed values has also reported a good model fit with $\chi^{2}=820.363$, and $d f=232$. Overall fit indices also have reported a good model fit $(\mathrm{CMIN} / \mathrm{df}=1.607$, $\mathrm{CFI}=.904$, and RMSEA=.042). The results of the comparison of $\chi^{2}$ values and other model fit indices are given in the table 2.

Information presented in table 2 indicates that the Chi-Square value has increased for the constrained model by $\Delta \chi^{2}=415.608$ and $\Delta d f=6$ and the difference for the two models was significant at zero. This result provides clear evidence for inequality of parameters on the structural paths between proactiveness, innovativeness, risk-taking and performance across low and high ACAP groups. Standardized $\beta$ values for the structural paths of the baseline model across two groups were given in the table 3 . The $\beta$ values in the table 3 indicate that the effect of high ACAP group on the relationship between proactiveness, innovativeness, isk-taking and performance is higher while there is a comparatively lower effect from low ACAP group. For example, the effect of high ACAP group on the relationship between proactiveness and performance indicates a value of .64 p< .000. However, the same value for low ACAP group is .38, $\mathrm{p}<.000$ which shows a significant deterioration compared to high ACAP group. This is true for the other two estimated paths.

The squared multiple correlations for estimated parameters were also used to determine the explained variance of the dependent variable by the independent variables (Byrne, 2010). Table 4 displays the estimated squared multiple correlations values for variables.

As per the table 4, variance of performance explained by proactiveness, innovativeness and risktaking in low ACAP group was considerably lower than that of high ACAP group. For example, the variance of performance explained by proactiveness for ACAP capacity group is .372 while it is .781 for higher ACAP group. The squared multiple correlations for innovativeness and risk-taking for low ACAP group is .364 and .332 respectively. The same values for high ACAP group is .674 and .563 respectively. It clearly shows that the variance explained in low ACAP group is less than that of high ACAP group.

A summary of the results of the chi square difference test between baseline model and constrained model, parameter estimation and squared multiple correlations for low and high ACAP groups are given in the table 5 .

\section{Testing Hypotheses}

As shown in the table 1, the regression parameters for three direct paths are in the expected direction $(\beta>0)$ and statistically significant $(p<.001) . \beta$ value estimated for the direct path from proctiveness to performance reports .62 and therefore the hypothesis $\mathrm{H}_{1}$ is accepted. Hypothesis $\mathrm{H}_{2}$ that represents the direct path from innovativeness and firm performance is accepted with estimated $\beta$ value of .28. The hypothesized path from risk-taking to firm performance reports .20 and $\mathrm{H}_{3}$ also accepted. 
First moderating hypothesis of the study, $\left(\mathrm{H}_{4}\right)$ was that ACAP moderates the relationship between proactiveness and firm performance. Results of chi square difference test showed the existence of moderating effect of ACAP on the relationship between the variables. Regression estimates for the high ACAP group and low ACAP group were .64 and .38 respectively. Squared multiple correlations for low ACAP group was .372 and for high ACAP group .781. This result proved that effect of ACAP on the relationship between proactiveness and performance was greater in higher ACAP SMEs. Therefore, $\mathrm{H}_{4}$ can be accepted.

Second moderating hypothesis $\left(\mathrm{H}_{5}\right)$ was that ACAP moderates the relationship between innovativeness and firm performance. Results of chi square difference test showed the existence of moderating effect of ACAP on the relationship between innovativeness and performance. Regression weight for low ACAP group .01 and for high ACAP group is .20. It shows that the effect of innovativeness on performance is low in low ACAP group. It is further verified by squared multiple correlations values for the two groups. Squared multiple correlation for low acap group and high acap group is .364 and .674 respectively. These results proved that the effect of innovativenes on performance is higher in high ACAP firms than low ACAP firms. These results supported the hypothesis and $\mathrm{H}_{5}$ is accepted.

$\mathrm{H}_{6}$ hypothesized that ACAP moderates the relationship between risk-taking and firm performance. Results of the chi square difference test between baseline model and constrained model has supported the existence of moderating effect. $\beta$ coefficient for the path from risk-taking to firm performance in low ACAP group .01 and the same value for the same relationship in higher ACAP group was .38. It shows that the value is greater in higher ACAP group. Squared multiple correlations values for the relationship between risk-taking and performance in low ACAP group .332 and the same value for high ACAP group is .563 . These results indicated that the relationship between risk-taking and performance is higher in high ACAP group than in low ACAP group. Therefore, the hypothesis $\mathrm{H}_{4 \mathrm{c}}$ is supported by the findings.

\section{Discussion and Conclusion}

The current study argued that the dimensions of entrepreneurial orientation as a strategic orientation would be a good predictor variable to the firm performance. This argument is supported by the findings. The results imply that being proactive, innovative, and inclined to take risk were more important in achieving firm performance. The findings of the study confirm the findings of the majority of previous similar studies (i.e. Becherer and Maurer, 1997; Atuahene-Gima and Ko, 2001; Frishammar and Horte, 2007; Deeds, 2001)

Study found clear statistical evidence for moderating impact of absorptive capacity on the relationship between the dimensions of entrepreneurial orientation and firm performance. This result theoretically implies that entrepreneurial orientation with higher 
absorptive capacity would improve the performance of SMEs by further confirming the core implications of the theories of entrepreneurial orientation and Dynamic capabilities. The findings were also in consistent with the premise behind resource based theory and the knowledge based view. The practical implications of the findings invite managers to improve the level of entrepreneurial orientation at the organizational level by paying more attention to its dimensions. Meanwhile, the capacity of the organization for the absorption of the knowledge has to be improved and the learning environment within the organization are to be created by ensuring the smooth implementation of knowledge management process in the organization. The findings also open further avenues for future researchers to test the similar models in different contexts specially paying more attention to the absorptive capacity of the firm, its dimensions and the knowledge management process in the organization to reconfirm the moderating effects tested in the research model of this study.

\section{References}

Agrawal, M. (2007). Entrepreneurial human capital and new venture performance: In search of illusive link. Academy of Entrepreneurship Journal, 13(1), 1-22.

Altenburg, T., \& Eckhardt, U. (2006). Productivity Enhancement and Equitable Development: Chellenges for SME Development. Vienna: United Nations Industrial Development Organization.

Asian Productivity Organization. (2011). APO Productivity Data Book. Japan: Keio University Press Incorporation.

Astrid, S., Cristina, C., \& Ruzana, A. (2008). Building absorptive capacity in less developed countries: The Case of Tanzania. Retrieved February 18, 2012, from Circle, Lund University: http://www.circle.lu.se/publications

Atuahene-Gima, K., \& Ko, A. (2001). An empirical investigation of the effect of market orientation and entrepreneurship orientation alignment on product innovation. Organization science, 12 (1), 57-74.

Baker, W. E., \& Sinkula, J. M. (2009). The complmentary effects of market orientation and entrepreneurial orientation on profitability in small businesses. Journal of Small Business Management, 47 (4), 443-464.

Barrett, A., Balloun, J., \& Weinstein, A. (2005). The impact of creativity on performance in non-profits. International Journal of Non-profit and Voluntary Sector Marketing, 10 (4), 213-223.

Becherer, R. C., \& Maurer, J. G. (1997). The moderating effect of environmental variables on the entrepreneurial orientation and marketing orientation of entrepreneur-led firms. Entrepreneurship Theory and Practice, 22 (1), 47-58. 
Beneki, C., Papastathopoulos, A. (2011). A log linear analysis of factors affecting performance of European manufacturing SMEs. International Journal of Management and Marketing Research, 4 (3), 75-93.

Bergh, D., \& Lim, E. (2008). Learning how to restructure absorptive capacity and improvisational views restructuring actions and performance. Strategic Management Journal, 29, 593-616. DOI: 10.1002/smj.676

Bhuian, S. N., Menguc, B., \& Bell, S. J. (2005). Just entrepreneurial enough: The moderating effect of entrepreneurship on the relationship between market orientation and performance. Journal of Business Research, 58 (1), 9-17. DOI:10 .1016/S0148-2963(03)00074-2

Brettel, M., Greve, G. I., \& Flatten, T. C. (2011). Giving up linearity: Absorptive capacity and performance. Journal of Managerial Issues, 2 (summer), 164189.

Brush, C. G., \& Vanderwerf, P. A. (1992). A comparison of methods and sources for obtaining estimates of new venture performance. Journal of Business Venturing, 7 (March), 157-170.

Carton, R. B., \& Hofer, C. W. (2010). Organizational financial performance: Identifying and testing multiple dimensions. Academy of Entrepreneurship Journal, 6 (1), 1-22.

Chandrakumara, A., De Zoysa, A., \& Manawaduge, A. (2011). Effect of the entrepreneurial and managerial orientations of owner-managers on company performance: An empirical test in Sri Lanka. International Journal of Management, 28 (1), 139-151.

Cohen, W. M., \& Levinthal, D. A. (1990). Absorptive Capacity: A new perspective of learning innovation. Administrative Science Quarterly, 35 (1), 128-152.

Cohen, W., \& Levinthal, D. (1989). Innovation and learning: The two faces of R \& D. Economic Journal, 99 (397), 569-596.

Covin, G. J., \& Lumpkin, G. T. (2011). Entrepreneurial Orientation Theory and Research: Reflections on a Needed Construct, Entrepreneurship Theory and Practice 35 (5), 855-872.

Covin, G. J., \& Selvin, D. P. (1991). A conceptual model of entrepreneurship as firm behavior. Entrepreneurship Theory and Practice 16 (1), 7-25.

Covin, J. G., \& Selvin, D. P. (1989). Strategic management of small firms in hostile and Benign environment. Strategic Management Journal, 10, 75-87.

Deeds, D. (2001). The role of R\&D intensity, technical development and absorptive capacity in creating entrepreneurial wealth in high technology start-ups. Journal of Engineering and Technology Management, 18, 29-48. DOI. 10.1016/S092 3-4748(00)00032-1 
Emine, D. (2012). Financial challenges that impede increasing the productivity of SMEs in Arab region. Journal of Contemporary Management, 1, 17-32.

Enriquez, L. A., Adame, M., \& Camacho, R. R. (2011). Small business competitiveness model for strategic sectors. Advances in Competitiveness Research, 19 (3/4), 58-73.

Fauzul, M. F., Takenouchi, H., \& Yukiko, T. (2010). Entrepreneurial orientation and business performance of small and medium scale enterprises in Sri Lanka. Asian Social Science, 6 (3), 34-46.

Flatten, T. C., Greve, G. I., \& Brettel, M. (2011). Absorptive capacity and firm performance in SMEs: The mediating influence of strategic alliances. European Management Review, 8, 137-152. DOI: 10.1111/j.17404762.2011.01015.x

Foley, P., \& Green, H. (1989). Small business success. London: Chapman.

Frishammar, J., \& Andersson, S. (2009). The overestimated role of strategic orientations for international performance of SMEs. Journal of Entrepreneurshi p, 7, 57-77. DOI: 10.1007/s10843-008-0031-9

Frishammar, J., \& Horte, S. A. (2007). The role of market orientation and entrepreneurial orientation for new product development performance in manufacturing firms. Technology Analysis and Strategic Management, 19 (6), 765-788. DOI: 10.1080/09537320701711231

George, G. S., Zahra, K., Wheatley, \& Khan, R. (2001). The effect of alliance portfolio characteristics and absorptive capacity on performance: A study of biotechnology firms. The Journal of High Technology Management Research, 12, 205-226.

Grant, R. M. (1996). Toward a knowledge-based theory of the firm. Strategic Management Journal, 17(winter), 109-122.

Hakala, H. (2010). Configuring out strategic orientation. Finland, vassa: University of Vassa.

Harvey, G., Skelcher, C., Jas, P., \& Walshe, K. (2010). A knowledge-based approach to analyzing the performance of sector organizations. Public Management Review, 12 (1), 77-97. DOI: 10.1080/14719030902817923

Hayton, J., \& Zahra, S. (2005). Venture team human capital and absorptive capacity in high technology new ventures. International Journal of Technology Management, 31(3/4), 256-274.

Hoq, M. Z., \& Chauhan, A. A. (2011). Effects of organizational resources on organizational performance: An empirical study of SMEs. Interdisciplinary Journal of Contemporary Research in Business, 2 (12), 373-385. 
Hou, J. J. (2008). Toward a research model of market orientation and dynamic capabilities. Social Behavior and Personality, 36 (9), 1251-1268.

Huang, F., \& Rice, J. (2009). The role of absorptive capacity in facilitating "open innovation" outcomes: A study of Australian SMEs in the manufacturing sector. International Journal of Innovation Management, 13 (2), 201-220.

Hult, G. T., Hurley, R. F., \& Knight, G. A. (2004). Innovativeness: Its antecedents and impact on business performance. Industrial Marketing Management, 33 (5), 429-438.

Inmyxai, S., \& Takahashi, Y. (2009). Entrepreneurs as decisive human resources and business performance for the Lao SMEs. Chinese Business Review, 8 (7), 2943.

Islam, M. A., Khan, M. A., \& Obaidullah, A. M. (2011). Effect of entrepreneur and firm characteristics on the business success of SMEs in Bangladesh. International Journal of Business Management, 6 (3), 289-299.

Jolly, D. R., \& Therin, F. (2007). New venture technology sourcing: Exploring the effect of absorptive capacity, learning attitudes and past performance. Innovation, Management, Policy and Practice, 9 (3-4), 235-248.

Kaplan, R. S., \& Norton, D. P. (1996). The balanced score card: Translating the strategy into action. Boston: Harvard Business School Press.

Kim, C., Zhan, W., \& Erramilli, M. K. (2011). Resources and performance of international joint ventures: The moderating role of absorptive capacity. Journal of Asia Business Studies, 5 (2), 145-160. DOI: $10.1108 / 15587891111152311$

Klette, T. J., \& Johensen, F. (1998). Accumulation of R\&D capital and dynamic firm performance: A not-so-fixed effect model. ANNALES D'E'CONOMIE ET DE STATISTIQUE, 49, 389-419.

Kropp, F., Lindsay, N. J., \& Shoham, A. (2006). Entrepreneurial, market and learning orientations and international entrepreneurial business venture performance in South African firms. International Marketing Review, 23 (5), 504-523.

Kreiser, P. M., \& Davis, J. (2010). Entrepreneurial orientation and firm performance: The unique impact of innovativeness and risk taking. Journal of Small Business and entrepreneurship , 23 (1), 39-51.

Lane, P. J., Koka, B. R., \& Pathak, S. (2006). The reification of absorptive capacity: A critical review and rejuvenation of the construct. Academic Management Review, 31 (4), 833-863.

Lane, P. J., Salk, J. E., \& Lyles, M. A. (2001). Absorptive capacity, learning and performance in international joint ventures. Strategic Management Journal, 22, 1139-1161. DOI: $10.1002 /$ smj.206 
Leitner, K. H., \& Idenberg, S. G. (2010). Generic strategies and firm performance in SMEs: A longitudinal study of Australian SMEs. Small Business Economics, 35 (November), 169-189. DOI: 10.1007/s11187-009-9239-x

Li, J. J. (2005). The formation of Managerial networks of foreign firms in China: The effects of strategic orientations. Asia Pacific Journal of Management, 22 (4), 423-443.

Li, Y., Liu, Y., \& Zhao, Y. (2006). The role of market and entrepreneurial orientation and internal control in the new product development activities of Chinese firms. Industrial Marketing Management, 35 (3), 336-347.

Li, Y., Zhao, Y., Tan, J., \& Liu, Y. (2008). Moderating effect of entrepreneurial orientation on market orientation-performance linkage: Evidence from Chinese small firms. Journal of Small Business Management, 46 (1), 113133.

Liao, J., Welsch, H., \& Stoica, M. (2003). Organizational absorptive capacity and responsiveness: An empirical investigation of growth-oriented SMEs. Entrepreneurship Theory and Practice, 25 (4), 63-85.

Lichtenthaler, U. (2009). Absorptive capacity, environmental turbulence, and the complimentarily of organizational learning processes. Academy of Management Journal, 52, 822-846.

Lin-Van, Y., De-Van, Y., \& Yun-Horng, R. (2010). Learning and innovation in small and medium enterprises. Industrial Management Data and Systems, 110 (2), 175-192. DOI: 10.1108/02635571011020296

Liu, S. S., Luo, X., \& Shi, Y. Z. (2003). Market oriented organizations in an emerging economy: A study of missing links. Journal of Business Research, 56 (6), 481-491. DOI: 10.1016/S0148-2963(01)00265-X

Lumpkin, G. T., \& Dess, G. G. (1996). Clarifying the entrepreneurial orientation construct and linking it to performance. Academy of Management Review, 21 (1), 135-172.

Luo, X., Sivakumar, K., \& Liu, S. S. (2005). Globalization, marketing resources, and performance: Evidence from China. Academy of Marketing Science Journal, 33 (1), 50-65. DOI: 10.1177/0092070304265050

Mancinelli, S., \& Mazzanti, M. (2009). Innovation, networking and complimentarily: Evidence on SME performance for a local economic system in North-Eastern Italy. Ann Reg science, special issue, 567-597. DOI: 10.1007/s00168-0080255- 6

March, J. G., \& Sutton, R. I. (1997). Organizational performance as a dependent variable. Organizational Science, 8 (6), 698-706. 
Miller, D. (1983). The correlates of entrepreneurship in three types of firms. Management Science, 29, 770-791.

Murphy, G. B., Trailer, G. W., \& Hill, C. (1996). Measuring performance in entrepreneurship research. Journal of Business Research, 36, 15-23.

Murray, T. S., \& Peyrefitte, J. (2007). Knowledge type and communication media choice in the knowledge transfer process. Journal of Managerial Issues, 19(spring), 111-133.

Muscio, A. (2007). The impact of absorptive capacity on SMEs collaboration. Economics of Innovation and New Technology, 16, 653-668.

Newbert, S. L., Gopalakrishnan, S., \& Kirchoff, B. A. (2008). Looking beyond resources: Exploring the importance of entrepreneurship to firm level competitive advantage in technologically intensive industries. Technovation, 28, 6-19.

Ng, D. (2011). Thinking outside the box: An absorptive capacity: Approach to the product development process. International Food and Agribusiness Management Review, 14 (3), 67-94.

Panday, V. M. (2012). Comparative analysis of development of SMEs in developed and developing countries. Proceedings of the 2012 International Conference on Business and Management, (pp. 426-433). Phuket-Thailand: CAALInternational Education

Parida, V. (2009). Role of entrepreneurial orientation in overcoming the competency trap of absorptive capacity. Frontiers of Entrepreneurship Research, available at: http:// digitalknowledge.babson.edu/fe/vo129/iss4/9 .

Rogers, E. W., \& Wright, P. M. (1998). Measuring Organizational performance in strategic human resource management: Looking beyond the lamp-post. Retrieved December 12, 2011, from http://www..ilr.cornel.edu/cahrs

Ruokonen, M., \& Saarenketo, S. (2009). The strategic orientations of rapidly internationalizing software companies. European Business Review, 21 (1), 17-41. DOI: 10.1108/09555340910925166

Schindehutte, M., Morris, M. H., \& Kocak, A. (2008). Understanding market driving behavior: The role of entrepreneurship. Journal of Small Business Management, 46 (1), 4-26.

Schoot, R. V., Lugtig, P., \& Hox, J. (2012). A checklist of testing measurement invariance. European Journal of Developmental Psychology, 9 (4), 486-492. DOI:10.1080/1740562 9.2012.686740 
Sher, P. J., \& Lin, C. H. (2006). Small and medium size enterprises' performance: Network and absorptive capacity perspectives. Proceedings at PICMET conference 2006 (pp. 9-13). Istanbul: Portland International Center for Management of Engineering Technology.

Sinkula, J. M., Baker, W. A., \& Noordewier, T. (1997). A framework for market based organizational learning: Linking values, knowledge, and behavior. Academy of Marketing Science Journal, 25 (4), 305-318.

Subhan, Q. A., Mehmood, M. R., \& Sattar, A. (2013). Innovation in small and medium enterprises and its impact on economic development in Pakistan. Proceedings of 6th international business and social sciences research conference (pp. 1-18). Dubai: World Academy of Social Sciences.

Sun, P. Y., \& Anderson, M. H. (2010). An examination of the relationship between absorptive capacity and organizational learning and a proposed integration. International Journal of Management Reviews, 12 (2) 130-150. DOI:10.1111/j. 1468-2370.2008.00256.x

Tajeddini, K. (2010). Effect of customer orientation and entrepreneurial orientation on innovativeness: Evidence from the hotel industry in Switzerland. Tourism Management, 31(2), 221-231. DOI: 10.1016/j.tourman.2009.02.013

Tang, L., \& Koveos, P. E. (2004). Venture Entrepreneurship, Innovation Entrepreneurship and Economicn Growth. Journal of Developmental Entrepreneurship, 9 (2), 161-171.

Teece, D. J., \& Pisano, G. (1994). The dynamic capabilities of firms: An introduction. Industrial and Corporate Change, 3 (3), 537-556.

Tzokas, N., Carter, S., \& Kyriazopoulos, P. (2001). Marketing and entrepreneurial orientation in small firms. Enterprise and Innovation Management Studies, 2 (1), 19-33. DOI: 10.1080/146324401 10056625

Venkatraman, N., \& Ramanujam, V. (1986). Measurement of business performance in strategy research: A comparison of approaches. The Academy of Management Review, 11 (4), 801-814.

Wang, C. L. (2008). Entrepreneurial orientation, learning orientation and firm performance. Entrepreneurship Theory and Practice, 32 (4), 635-657.

Wang, C., \& Han, Y. (2011). Linking properties of knowledge with innovation performance: The moderate role of absorptive capacity. Journal of Knowledge Management, 15 (5), 802-819. DOI: 10.1108/13673271111174339

Wiklund, J., \& Shepherd, D. (2005). Entrepreneurial orientation and small business performance: A configurational approach. Journal of Business Venturing , 20 (1), 71-91. 
Wymenga, P., Spanikova, V., Barker, A., Konings, J., \& Canton, E. (2012). European Union SMEs in 2012: Annual report on small and medium-sized enterprises in the European Union. Rotterdam: European Union.

Yang Chao, G., Shun Lin, Y., Lin Cheng, Y., \& Chia Liao, S. (2011). A research on the relationship among market orientation, absorptive capability, organizational innovation climate and innovative behavior in Taiwan's manufacturing industry. African Journal of Business Management, 5 (19), 7855-7863.

Yeoh, P. (2009). Realized and potential absorptive capacity: Understanding their antecedents and performance in the sourcing context. Journal of Marketing Theory and Practice, 17 (1), 21-36. DOI: 10.2753/MTP1069-6679170102

Zahra, S., \& George, A. G. (2002). Absorptive capacity: A review, reconceptualization, and extension. Academic Management Review, 27 (2), 185-203.

Zhang, D. D. (2009). Absorptive capacity and its mediating effect on the learning and market orientations' influence on performance. International Journal of Technology Marketing, 4 (2/3), 275-288.

Zhou, K. Z., \& Li, C. B. (2010). How strategic orientations influence the building of dynamic capability in emerging economies. Journal of Business Research, 63, 224-231. DOI:10.1016/j.jbusres.2009.03.003

Zonooz, B. H., Farzam, V., Satarifar, M., \& Bakhshi, L. (2011). The relationship between knowledge transfer and competitiveness in SMEs with emphasis on absorptive capacity and combinative capabilities. International Business and Management, 2 (1), 59-85. 


\section{Appendices}

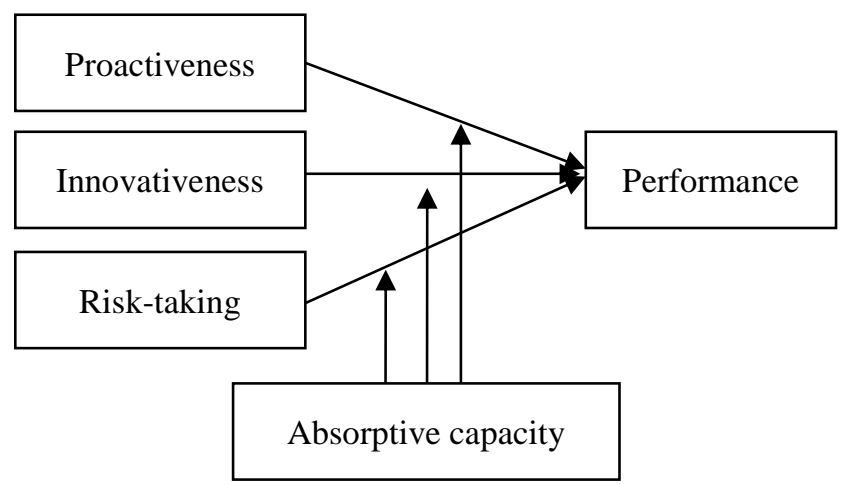

Figure 01: Research Model

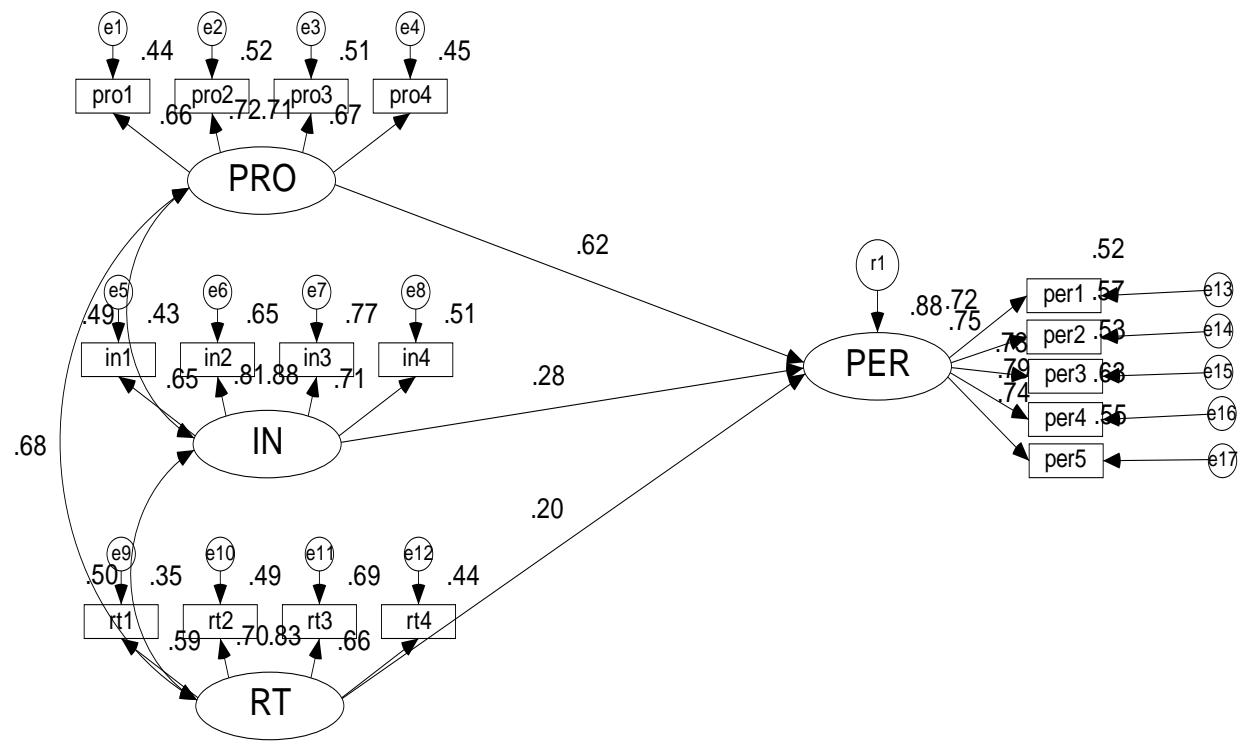

pro $=$ proactiveness, in $=$ innovativeness,$r s=$ risk-taking, $\mathrm{ACAP}=$ absorptive capacity, $\mathrm{PER}=$ performance

\section{Figure 02: Structural Equation Model}




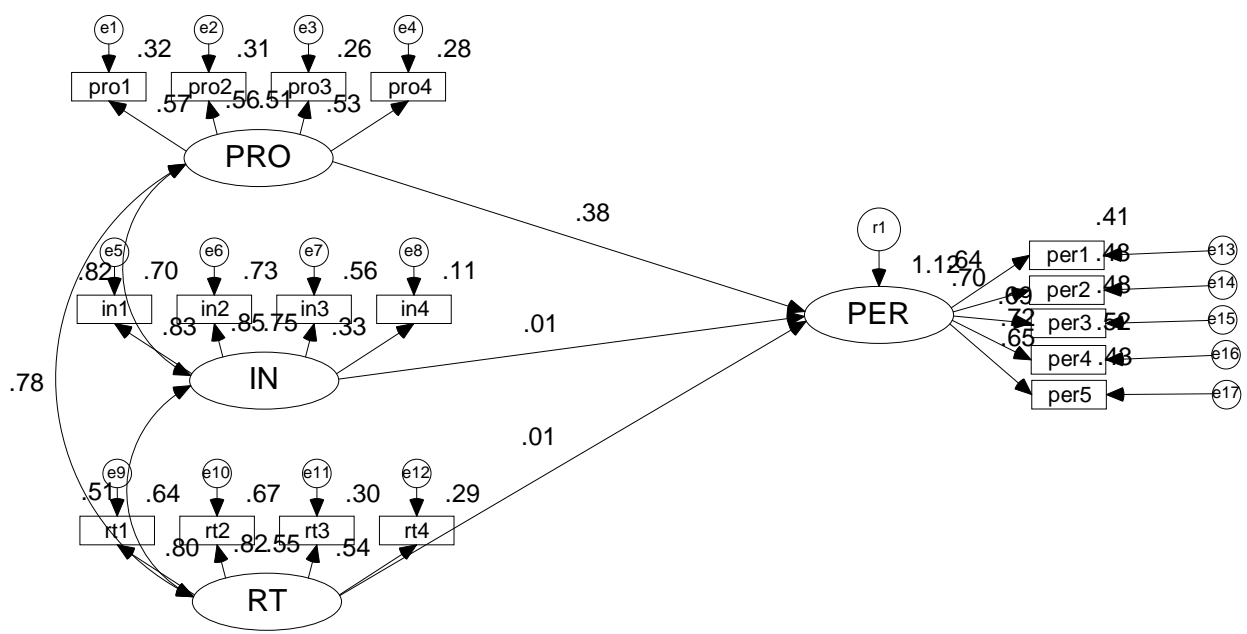

Figure 3: Structural Equation Model for Direct Effects

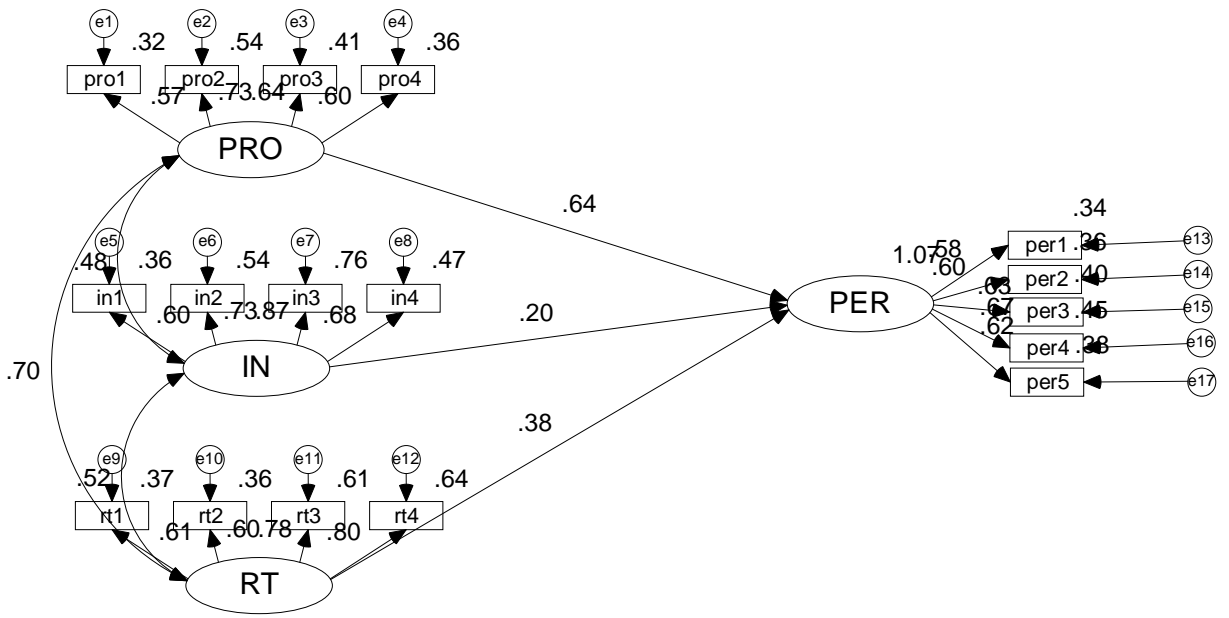

Figure 4: Structural Equation Baseline model for Low ACAP group 
Herath, KJHRM 2020, 15(01)

Table 1: Estimated Regression Weights for Direct Paths

\begin{tabular}{lc}
\hline Direct path & Standardised regression weight \\
\hline PRO $>$ PER & .62 \\
\hline IN $>$ PER & .28 \\
\hline RT $>$ PER & .20 \\
\hline
\end{tabular}

Table 2: Results of Multi Group Analysis

\begin{tabular}{lccccc}
\hline Model & $\chi^{2}$ & $d f$ & $\chi / d f$ & CFI & RMSEA \\
\hline $\begin{array}{l}\text { Configural model with all } \\
\text { parameters free across groups }\end{array}$ & 471.389 & 226 & 2.086 & .898 & .056 \\
\hline $\begin{array}{l}\text { Model with constrained parameters } \\
\text { across two groups }\end{array}$ & 886.989 & 232 & 3.823 & .728 & .060 \\
\hline Difference & 415.608 & 06 & & & \\
\hline
\end{tabular}

Table 3: Estimated Parameters for High and Low ACAP Groups

\begin{tabular}{|c|c|c|}
\hline Structural Path & $\begin{array}{l}\text { Low ACAP } \\
\text { group }(\beta)\end{array}$ & $\begin{array}{l}\text { High ACAP group } \\
(\beta)\end{array}$ \\
\hline PRO > PER & $.38^{*}$ & $.64^{*}$ \\
\hline IN $>$ PER & $.01 *$ & $.20 *$ \\
\hline RT > PER & $.01 *$ & $.38 *$ \\
\hline
\end{tabular}

\section{Table 4: Squared Multiple Correlations}

\begin{tabular}{lcc}
\hline Structural Path & $\begin{array}{l}\text { Low ACAP } \\
\text { group (SMC) }\end{array}$ & $\begin{array}{l}\text { High ACAP group } \\
\text { (SMC) }\end{array}$ \\
\hline PRO > PER & .372 & .781 \\
\hline IN $>$ PER & .364 & .674 \\
\hline RT $>$ PER & .332 & .563 \\
\hline
\end{tabular}

Table 5: Summary results of Testing Moderating Effects

\begin{tabular}{cccccc}
\hline Moderating & \multirow{2}{*}{$\chi^{2}$} & \multicolumn{2}{c}{$\beta$ for ACAP groups } & \multicolumn{2}{c}{ SMC for ACAP groups } \\
\cline { 3 - 6 } path & difference & Low & High & Low & High \\
\hline PRO $>$ PER & significant & .38 & .64 & .372 & .781 \\
\hline IN $>$ PER & significant & .01 & .20 & .364 & .674 \\
\hline RT $>$ PER & significant & .01 & .38 & .332 & .563 \\
\hline
\end{tabular}

